\section{'Viradoro': A Tospovirus-resistant Processing Tomato Cultivar Adapted to Tropical Environments}

\author{
Leonardo de B. Giordano, Antônio Carlos de Ávila, João Maria \\ Charchar, and Leonardo S. Boiteux \\ Centro Nacional de Pesquisa de Hortaliças (CNPH)_Empresa Brasileira de \\ Pesquisa Agropecuária(EMBRAPA), C.P.218, 70359-970, Brasília-DF, Brazil
}

\section{Edinardo Ferraz}

Instituto Pernambucano de Pesquisa Agropecuária (IPA), Av. General San Martin 1371, Bonji, 50761-000, Recife, Pernambuco-PE, Brazil

Additional index words. Lycopersicon esculentum, Fusarium oxysporum, Verticillium dahlie, Stemphyllium solani, Macrosiphum euphorbiae, Meloidogyne sp., tomato spotted wilt

tospovirus, tomato chlorotic spot tospovirus, groundnut ring spot tospovirus, disease, breeding

The production of processing tomatoes in Brazil has been dominated over the last decade by open-pollinated cultivars with 'IPA-5' as the leading commercial cultivar. This scenario has changed in recent years with a significant increase in $\mathrm{F}_{1}$ hybrids, accounting for $12 \%$ and $45 \%$ of the total acreage in 1997 and 1998 , respectively. The estimated area planted to hybrids in 1999 was $80 \%$. 'IPA-5' is still the leading open-pollinated processing cultivar because of its high level of heat tolerance and relatively stable performance across all production regions of the country. In addition, 'IPA-5' has acceptable fruit color and firmness, as well as resistance to verticillium wilt race 1 (Verticillium dahlie Kleb.), fusarium wilt race 1 (Fusarium oxysporum f.sp. lycopersici race 1 sensu Gabe), gray leaf spot [Stemphylium solani Weber and S. lycopersici (Enjoji) Yamamoto], and root-knot nematodes (Meloidogyne sp. Goeldi). However, tospovirus infection has caused severe economic losses in production fields of 'IPA-5' (Fajardo et al., 1997) as well as in all other processing tomato cultivars and hybrids presently grown in Brazil (Giordano et al., 1998).

Severe tospovirus epidemics have been reported as major problems affecting freshmarket tomato crops in Brazil since the 1930s (Azevedo, 1936; Bitancourt, 1936), but is a relatively new problem for the Brazilian processing tomato industry. This disease was first designated as "vira-cabeça" (Portuguese for "upside down") because of the typical downward curling of the plant apex as a consequence of the apical chlorosis and necrosis (Silberschmidt, 1937). Costa and Foster (1941) identified the causal agent as tomato spotted

Received for publication 6 May 1999. Accepted for publication 12 Apr. 2000. We are grateful to Drs. P.W. Simon and S.J. Peloquin (Univ. of WisconsinMadison) for reviewing the manuscript. The cost of publishing this paper was defrayed in part by the payment of page charges. Under postal regulations, this paper therefore must be hereby marked advertisement solely to indicate this fact.

wilt virus (TSWV). Over the years, TSWV has been placed as the type species within the genus Tospovirus in the Bunyaviridae family (Francki et al., 1991). More recently, extensive molecular and biological studies using several isolates of worldwide origin indicated

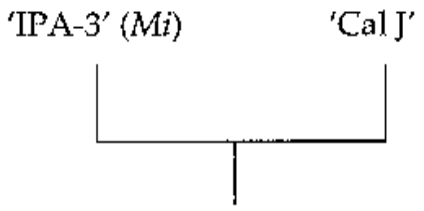

'IPA-5'

$(\mathrm{HT} / \mathrm{Mi} / \mathrm{Sm} / \mathrm{Ve} / \mathrm{I} / \mathrm{j} / \mathrm{sp})$ that the Tospovirus genus comprises a complex of at least nine distinct virus species (de Ávila et al., 1993, 1998). Four species were detected infecting processing tomato under natural conditions in Brazil: TSWV, tomato chlorotic spot virus (TCSV), groundnut ring spot virus (GRSV), and chrysanthemum stem necrosis virus (CSNV) (Boiteux and Giordano, 1993; de Ávila et al., 1993; Duarte et al., 1995).

Genetic resistance is one of the few practical strategies to control tomato infection by tospoviruses; chemical and cultural controls are either noneffective or costly (Ullman et al., 1997). A monogenic source of resistance to TSWV was found in the South African tomato cultivar Stevens, and the resistance locus was named $S w-5$ (Stevens et al., 1992). Additional studies indicated that the $S w-5$ locus also conditions effective levels of resistance against TCSV and GRSV isolates (Boiteux and Giordano, 1993). These features of the $S w-5$ locus created the possibility of developing new cultivars with resistance to a broad spectrum of tospovirus species, using relatively simple breeding strategies.

Because of the economic damage caused by tospoviruses in virtually all areas of Brazil producing tomato for processing, EMBRAPAIPA began a breeding program directed to-

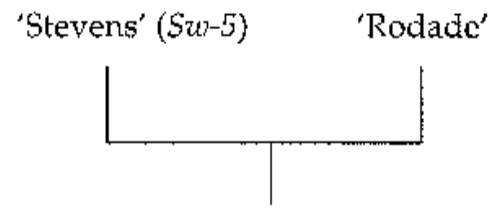

'TSW-10'

$(5 w-5 / S m / V e / I / j 2 / S p)$

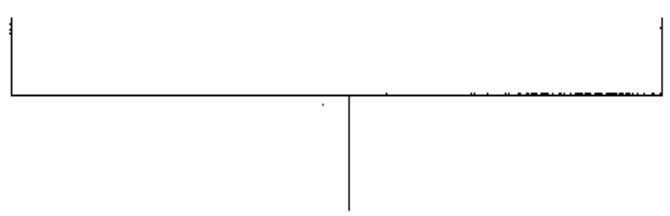

Four successive backeross generations to ' $1 \mathrm{PA} 5$ ' with progeny testing for resistance to tospoviruses

$$
\begin{gathered}
\mid \\
\text { 'Viradoro' } \\
\mathrm{F}_{5} \mathrm{BC} 4 \mathrm{population} \text { bulked } \\
\left(\mathrm{HT} / \mathrm{Mi} / S w-5 / S_{m} / V_{e} / \mathrm{I} / \mathrm{j} / \mathrm{sp}\right)
\end{gathered}
$$

Fig. 1. Pedigree, main attributes, and some of the major loci of the cultivar Viradoro. HT = heat tolerance; $M i=$ root-knot nematode/potato aphid resistance locus; $S w-5=$ tospovirus resistance locus; $S m=$ gray (Stemphylium) leaf spot resistance; $V e=$ verticillium wilt race 1 resistance; $I=$ resistance to fusarium wilt race 1; $s p=$ self-pruning locus; and $j 2=$ jointless fruit pedicel. 
ward the development of cultivars with the good horticultural characteristics of 'IPA-5' and resistance to tospoviruses. The result of this joint interregional and interinstitutional effort was the development of the multiresistant, heat-tolerant cultivar Viradoro.

\section{Origin}

'Viradoro' is an $\mathrm{F}_{5} \mathrm{BC}_{4}$ open-pollinated cultivar, which originated from a backcross program using 'IPA-5' (Ferraz et al., 1986) as the recurrent parent (Fig. 1). The nonrecurrent parental line was 'TSW-10', a fresh-market tomato inbred line resistant to Brazilian isolates of TSWV, TCSV, and GRSV (Boiteux et al., 1993a). The resistance to multiple tospovirus species was controlled by the presence of the $S w-5$ locus (chromosome 9) introgressed from L. peruvianum Mill. (Brommomschenkel and Tanksley, 1997; Stevens et al., 1992). Tomato lines carrying the $S w-5$ locus were resistant to tospoviruses in both greenhouse and field conditions in Brazil (Boiteux et al., 1993b; Giordano et al. 1994). Both parental lines used for the development of 'Viradoro' were previously selected for homozygosity at three loci controlling resistance to Fusarium oxysporum f.sp. lycopersici race 1 (locus $I$ ), $V$. dahlie race 1 (locusVe), and Stemphyllium solani and S. lycopersici (locus $\mathrm{Sm}$ ). Therefore, subsequent screening and selection cycles were primarily conducted for root-knot nematodes (locus $\mathrm{Mi}$ ) and tospoviruses (locus $S w-5$ ). Progeny testing for tospovirus resistance was conducted before each backcross cycle. Seedlings were mechanically inoculated with an assortment of isolates of TSWV, TCSV, and GRSV. Mechanical inoculation was conducted as described (Boiteux and Giordano, 1992). Only symptomless plants were backcrossed to 'IPA5'. 'Viradoro' and its sister lines $\left(\mathrm{F}_{5} \mathrm{BC}_{4}\right)$ were evaluated under greenhouse conditions for resistance to Meloidogyne javanica (Treub) Chitwood, M. incognita (Kofoid \& White) Chitwood (races 1, 2,3, and 4), and $M$. arenaria (Neal) Chitwood. Inocula were produced on the susceptible tomato cultivar Rutgers and collected from chopped roots shaken for $4 \mathrm{~min}$ in a beaker containing $1 \% \mathrm{NaOCl}$ solution (Hussey and Barker, 1973). Inoculation protocol and evaluation procedures were conducted as described by Boiteux and Charchar (1996) with minor modifications. Plants (at the fourleaf stage) were infested with a suspension of 6000 nematode eggs pipetted into depressions in the soil surface around the root systems. Healthy 'Rutgers' plants were infested with the same nematode suspension and employed as susceptible controls. 'Viradoro' exhibited resistant reaction to all Brazilian populations of M. javanica, M. incognita (races 1,2,3, and 4), and $M$. arenaria tested so far.

\section{Description}

'Viradoro' is a processing tomato cultivar developed for warm tropical and subtropical areas where simultaneous infection by tospoviruses and root-knot nematodes
(Meloidogyne sp.) are major economic constraints. 'Viradoro' is resistant to all species of the "Vira-cabeça" disease complex (caused by TSWV, TCSV, and GRSV). 'Viradoro' is also resistant to fusarium wilt race 1 ( $F$. oxysporum f.sp. lycopersici race 1) and verticillium wilt race 1 ( $V$. dahlie race 1$)$ as well as gray leaf spot (S. solani and S. lycopersici). 'Viradoro' is resistant to $M$. javanica, $M$. incognita (races $1,2,3$, and 4), and $M$. arenaria. In addition, because of the presence of the locus $M i$, 'Viradoro' is also resistant to some populations of the potato aphid Macrosiphum euphorbiae (Thomas) (Rossi et al., 1998). The resistance to $M$. euphorbiae conferred by this locus can indirectly reduce the incidence of some potyviruses transmitted by this aphid (Rossi et al., 1998).

'Viradoro' has indeterminate growth habit (locus $s p$ ) with vigorous foliage, which provides good fruit protection from sunscald. Ripe fruits of 'Viradoro' are firm, squareshaped (Fig. 2), with an average weight of 75 $\pm 5 \mathrm{~g}$. The external color is uniform and bright $\operatorname{red}(\mathrm{L}=38.0 ; \mathrm{a}=34.0 ; \mathrm{b}=21.0 ; \mathrm{a}: \mathrm{b}$ ratio $=$ 1.61). The average soluble solids ( ${ }^{\circ}$ Brix) of 'Viradoro' is $4.5 \% \pm 0.2 \%$, which is in the range reported for the recurrent parent 'IPA-5' (Boiteux et al., 1995; Giordano et al., 1997). 'Viradoro' has more uniform fruit ripening and earlier fruit setting than 'IPA-5', allowing mechanical harvesting nearly 100 to $120 \mathrm{~d}$ after plant emergence. This cultivar has the jointless phenotype (locus $j 2$ ), which facilitates both manual and machine harvesting. No major negative pleiotropic effects on agronomic and processing attributes have been reported in association with the $j 2$ gene in this genetic background (Boiteux et al., 1995).

'Viradoro' is also a potential line for $F_{1}$ hybrid production because of the dominance at numerous disease resistance loci, as well as acceptable agronomic and processing qualities. Experimental hybrids using 'Viradoro' as parental material are now being tested in Brazil.
Assessment of field performance under low and high tospovirus pressure and heat tolerance

'Viradoro' was evaluated in field trails with 'IPA-5' at two different locations in both semiarid tropical (Belém de São Francisco$\mathrm{PE})$ and highland subtropical (Brasília-DF) areas of Brazil. In Brasília with late tospovirus field infection (30-d-old plants transplanted to the field), 'Viradoro' significantly $(P \leq 0.05)$ outyielded 'IPA-5' with $103.8 \mathrm{t} \cdot \mathrm{ha}^{-1}$ vs. 94.3 $\mathrm{t} \cdot \mathrm{a}^{-1}$, respectively. None of the 'Viradoro' plants developed symptoms, whereas $30 \%$ of the 'IPA-5' plants showed typical tospovirus symptoms. The heat tolerance of 'Viradoro', as well as the importance of resistance to tospoviruses, was better evaluated in the field trial conducted at Belém do São Francisco (PE) in 1996. Under early tospovirus infection (direct sowing), 'Viradoro' (98.7 t.ha ${ }^{-1}$ ) outyielded 'IPA-5' (7.9 t.ha $\left.{ }^{-1}\right)$, with the latter cultivar suffering nearly $75 \%$ stand reduction (Giordano et al., 1998).

Resistance to root-knot nematodes is especially important in tropical and subtropical areas of the world, where continuous cropping of susceptible host plants may result in permanently infested soils. This scenario has been observed in processing tomato areas of Brazil (Giordano et al., 1997). The resistance of 'Viradoro' to Meloidogyne sp. was confirmed under greenhouse and also under naturally infested fields in Belém do São Francisco (PE). Resistance of 'Viradoro' to distinct Meloidogyne sp. populations was characterized by almost complete absence of gall and egg-mass formation, which is a similar response to that reported for $M i$ locus-incompatible populations (Roberts et al., 1992).

'Viradoro' has been also evaluated in large plots within production fields at several locations in Goiás and Minas Gerais States (central Brazil). In these commercial fields (conducted under either center-pivot or overhead sprin-

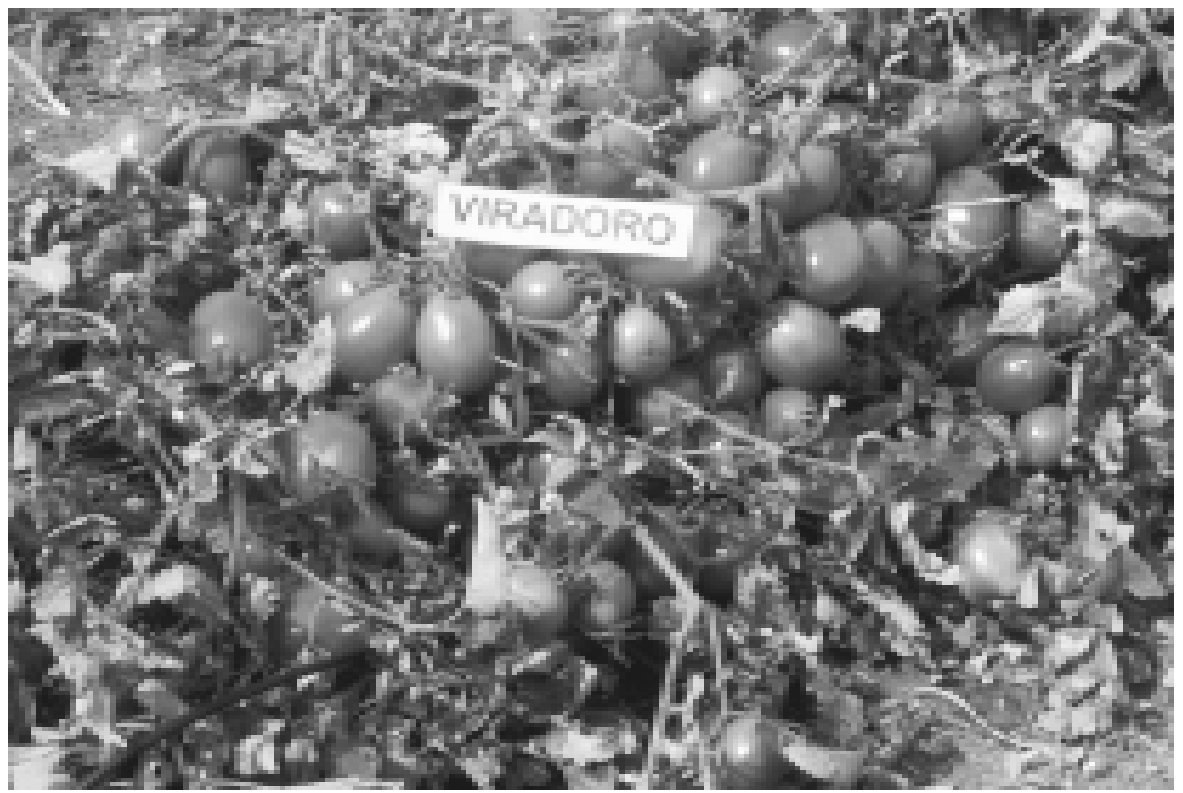

Fig. 2. Plants and fruits of the processing tomato cultivar Viradoro. 
kler irrigation), 'Viradoro' had average yields that consistently exceeded $80 \mathrm{t} \cdot \mathrm{ha}^{-1}$ with and without root-knot nematode and tospovirus infection.

\section{Seed availability}

Small quantities of seeds are available for farmers, research institutions, and seed companies upon request to EMBRAPA-CNPH and IPA. Both institutions will maintain the genetic seed stocks of 'Viradoro'.

\section{Literature Cited}

Azevedo, N. 1936. Observações sobre uma doença de vírus do tomate. Rodriguesia 6:209-212.

Bitancourt, A.A. 1936. A mancha anular do tomate. Biológico 2:98-100.

Boiteux, L.S. and J.M. Charchar. 1996. Genetic resistance to root-knot nematode (Meloidogyne javanica) in eggplant (Solanum melongena). Plant Breed. 115:198-200.

Boiteux, L.S. and L. de B. Giordano. 1992. Screening Lycopersicon germplasm for resistance to a Brazilian isolate of tomato spotted wilt virus. Tomato Genet. Coop. Rptr. 42:13-14.

Boiteux, L.S. and L. de B. Giordano. 1993. Genetic basis of resistance against two Tospovirus species in tomato (Lycopersicon esculentum). Euphytica 71:151-154.

Boiteux, L.S., L. de B. Giordano, A.C. de Ávila, and J.R.M. Santos. 1993a. 'TSW 10': Linhagen de tomate para mesa resistente a três espécies de tospovirus causadoras do 'vira-cabeça'. Hort. Bras. 11:163-164.

Boiteux, L.S., L. de B. Giordano, O. Furomoto, and F.A.S. Aragão. 1995. Estimating the pleiotropic effect of the jointless-2 gene on the processing and agronomic traits of tomato by using nearisogenic lines. Plant Breed. 114:457-459.
Boiteux, L.S., T. Nagata, and L. de B. Giordano. 1993b. Field resistance of tomato (Lycopersicon esculentum) lines to tomato spotted wilt disease. Tomato Genet. Coop. Rptr. 43:7-9.

Brommomschenkel, S.H. and S.D. Tanksley. 1997. Map-based cloning of the genomic region that spans the $S w-5$ tospovirus resistance gene in tomato. Mol. Gen. Genet. 256:121-126.

Costa, A.S. and R. Forster. 1941. Identidade do vírus de vira-cabeça e sua inclusão no grupo do virus de 'spotted wilt'. Bragantia 1:491-516.

de Ávila, A.C., P. de Haan, R. Kormelink, R. de O. Resende, R. Goldbach, and D. Peters. 1993. Classification of tospoviruses based on phylogeny of nucleoprotein gene sequences. J. Gen. Virol. 74:153-159.

de Ávila, A.C., L. Pozzer, I.C. Bezerra, R. Kormelink, M. Prins, D. Peters, T. Nagata, E.W. Kitajima, and R. de O. Resende. 1998. Diversity of tospoviruses in Brazil, p. 32-34. In: D. Peters and R. Goldbach (eds.). Recent progress in tospovirus and thrips research. 4th Symp. on Tospoviruses and Thrips in Floral and Veg. Crops, Wageningen, The Netherlands.

Duarte, L.M.L., E.B. Rivas, M.A.V. Alexandre, A.C. de Ávila, T. Nagata, and C.M. Chagas. 1995. Chrysanthemum stem necrosis caused by a possible novel tospovirus. J. Phytopathol. 143:569-571.

Fajardo, T.V.M., C.A. Lopes, W.L.C. Silva, and A.C. de Ávila. 1997. Dispersão da doença e redução da produção em tomateiro industrial infectado por tospovirus no Distrito Federal. Fitopatol. Bras. 22:413-418.

Ferraz, E., P.C.T. de Melo, J.T. Menezes, and J.A. Candeia. 1986. Cultivar de tomate IPA-5. Hort. Bras. 4:52.

Francki, R.I.B., C.M. Fauquet, D.D. Knudson, and F. Brown. 1991. Fifth Rpt. Intl. Comm. on Taxonomy of Viruses. Arch. Virol. 2:1-450.

Giordano, L. de B., L.S. Boiteux, and Y. Horino. 1994. Avaliação em condições de campo de genótipos de tomate para resistência a tospoviruses Hort. Bras. 12:176-178.

Giordano, L. de B., L.S. Boiteux, J.R.M. Santos, J.M. Charchar, and C.A. Lopes. 1997. 'Tx-40108': Linhagem de tomate para processamento industrial, com resistência múltipla a doenças. Hort. Bras. 15:123-126.

Giordano, L. de B., M.I. Lima, R. de O. Resende, E. Ferraz, and A.C. de Ávila. 1998. Developing tomato cultivars with resistance to tospovirus, $\mathrm{p}$. 97. In: D. Peters and R. Goldbach (eds.). Recent progress in tospovirus and thrips research. 4th Symp. on Tospoviruses and Thrips in Floral and Veg. Crops, Wageningen, The Netherlands.

Hussey, R.S. and K.R. Barker. 1973. A comparison of methods of collecting inocula of Meloidogyne spp. including a new technique. Plant Dis. Rptr. 57:1025-1028.

Peters, D. and R. Goldbach (eds.). Recent Progress in Tospovirus and Thrips Research. 4th Symp. on Tospoviruses and Thrips in Floral and Veg. Crops, Wageningen, The Netherlands.

Roberts, P.A., A. Dalmasso, G.B. Cap, and P. Castagnone-Sereno. 1990. Resistance in Lycopersicon peruvianum to isolates of $\mathrm{Mi}$ genecompatible Meloidogyne populations. J. Nematol. 22:585-589.

Rossi, M., F.L. Goggin, S.B. Milligan, I. Kaloshian, D.E. Ullman, and V.M. Williamson. 1998. The nematode resistance gene $\mathrm{Mi}$ of tomato confers resistance against the potato aphid. Proc. Natl. Acad. Sci. USA 95:9750-9754.

Silberschmidt, K.M. 1937. A doença vira cabeça do fumo. Biológico 3:183-184.

Stevens, M.R., S.J. Scott, and R.C. Gergerich. 1992. Inheritance of a gene for resistance to tomato spotted wilt virus (TSWV) from Lycopersicon peruvianum Mill. Euphytica 59:9-17.

Ullman D.E., J.L. Sherwood, and T.L. German 1997. Thrips as vectors of plant pathogens, $p$. 539-565. In: T. Lewis (ed.). Thrips as crop pests. CAB Intl., U.K 